i bibliograficznych, 5 prac popularno-naukowych, 6 recenzji, 3 opracowania redakcyjne, wreszcie liczne hasła w polskiej Encyklopedii Biblijnej oraz hiszpańskiej Encyklopedii Biblijnej wydawanej w Barcelonie od $1960 \mathrm{r}$.

Kraków

RED.

\title{
EKUMENISTYCZNY WIECZÓR BIBLIJNY ZA OCEANEM
}

Dzięki uprzejmości ks. prałata dra W. J. J a sińskiego, profesora Polskiego Seminarium Duchownego w Orchard Lake, w stanie Michigan, U.S.A., możemy podzielić się z czytelnikami opisem ekumenicznego wieczoru biblijnego, odbytego w dniu 17 stycznia b. r. z udziałem alumnów wspomnianego wyżej seminarium.

Ks. prałat T. Jobs z Orchard Lake oraz księża: J. H a yes i V. Oldani z Pontiac zwrócili się do Kurii arcybiskupiej w Detroit z prośbą o zezwolenie na urządzenie ekumenicznego wieczoru biblijnego z udziałem duchownych innych wyznań chrześcijańskich.

Kiedy zezwolenie nadeszło, ks. proboszcz Hayes z parafii św. Michała dał do dyspozycji na ten cel salę parafialną i on też otworzył wieczúr przywitaniem gości.

Następnie wniesiono na salę - w procesji - Pismo Swięte przy wspólnym śpiewie: „Praise to the Lord”.

Biblię, którą niósł alumn E. Poł cki, umieszczono na specjalnym stojaku pod dużym świetlanym krzyżem, rzuconym na ścianę przy pomocy reflektora. Na białym krzyżu odbijały się cienie metalowych linii Krucyfiksu, stojącego między ścianą i reflektorem.

Komentatorem wieczoru był student teologii Polskiego Seminarium Duchownego J. M i c hnowicz. Modlitwom zaś, tak śpiewanym jak recytowanym, przewodniczył ks. Miltiades $\mathrm{E} f \mathrm{th}$ i m i o u, proboszcz parafii grecko-prawosławnej w Detroit za zezwoleniem jego biskupa J. E. G e rm a n o s a.

Przed czytaniem pierwszej lekcji przewodniczący odmówił modlitwy wzięte z liturgii koptyjskiej św. Cyryla, poczem student Kolegium pod wezwaniem Najśw. Marii Panny w Orchard Lake, F. K o z a n, odczytał z Izajasza rozdział $60: 1-6$, a diakon ze Seminarium Polskiego, D. R o s h, wygłosił medytację, tłumacząc treść lekcji w świetle jej kontekstu biblijnego. W odpowiedzi na Słowo Boże obecni recytowali Psalm 64.

Drugie czytanie (I Jan 2, 1-17) i na nim oparte medytacje wygłosił Jack H. C. Cla rk, pastor kościoła First Christian Church w Pontiac, sekretarz okręgowy protestanckiej Rady Kościołów.

W odpowiedzi na te rozważania obecni odśpiewali chóralnie hymn: „Where Charity and Love Prevail".

Potem ks. Charles Colberg, pastor luterańskiej parafii pod wezwaniem Gloria Dei w Pontiac, przeczytał z Ewangelii św. Nateusza : 22, 34-40 i na tym tekście oparł swoją konferencję.

W nawiązaniu do wspomnianej konferencji obecni odśpiewali - przy udziale chóru studentów - antyfonę Alleluja i Psalm 99 według 'melodii Gelineau.

W czwartej, szczytowej części tego podniosłego i interesującego wieczoru ks, proboszcz Miltiades Efthimio u odczytał podniosłą i niezapomnianą Modlitwę Arcykapłańską Pana Jezusa z Ostatniej Wieczerzy (Jan 17).

W odpowiedzi na te przepiękne w treści i formie słowa modlitwy Zbawiciela, nie wymagające specjalnego objaśnienia, wszyscy uczestnicy 
wieczoru odpowiedzieli hymnem błagalnym, prosząc, aby Trójca Swięta zjednoczyła wszystkich, którzy ją adorują, śpiewając unisono: „Lord Unite All Who Adore Thee!"...

Poczem ks. M. Efthimiou odśpiewał melodie bardzo charakterystyczne dla kościoło grecko-prawosławnego, obejmujace wzruszającą Litanię i Suplikacje, w których błagamy Boga o odpuszczenie grzechów, popełnionych przez członków różnych wyznań chrześcijańskich i o miłosierdzie dla nich, prosząc, aby nareszcie doszło do zjednoczenia i uświęcenia: w prawdzie i miłości.

Fo każdej inwokacji wszyscy obecni odpowiadali: Kyrie Eleison (Panie, zmiłuj się...).

Po zakończeniu Suplikacji Wszyscy odmówili — stojąc - Skład Apostolski. Następnie uczestnicy odśpiewali hymn: „All Hail Adored Trynity".

Na zakończenie złożyło się: odmówienie „,Ojcze Nasz”, pobłogosławienie Biblią i odśpiewanie ,Te Deum” - po angielsku.

Dodać należy, że teksty modlitewne były aprobowane na ten Ecumenical Bible Service i przez Hierarchię Katolicką i przez Światową Radę Kościołów (World Council of Churches).

Stacja radiowa WFON z Pontiac nadawała program tego pięknego wieczoru przez całą godzinę.

Doradcą dla całości był - ze strony Polskiego Seminarium Duchownego w Orchard Lake - ks. prałat dr W. J. J a s i ńs ki, który - w bieżącym roku szkolnym - wykłada Dekrety II Soboru Watykańskiego o Ekumeniźmie i Kościele Wschodnim oraz encyklikę Ojca św. Pawła VI „Ecclesiam Suam”.

Kraków

KS. HENRYK WERYÑSKI

\section{PONADWYZNANIOWE STOWARZYSZENIE LITURGICZNE}

Dwudziestu jeden liturgistów z Europy i Stanów Zjednoczonych katolickich, prawosławnych, anglikańskich i protestanckich odbyło w kwietniu br. đoniosłą konferencję w mieście Neuchâtel, w zachodniej Szwajcarii. $\mathrm{Na}$ tej konferencji podjęto niezmiernie decydującą i nowatorską uchwałę, by powołać do życia ponadwyznaniowe Stowarzyszenie Liturgiczne. Stowarzyszenie to ma się nazywać Societas Liturgica.

$\mathrm{Na}$ wspomnianej wyżej konfereneji wyłonił się specjalny Komitet Wykonawczy, któremu powierzono opracowanie ramowych zarysów tego ponadwyznaniowego Stowarzyszenia Liturgicznego. Pierwsze posiedzenie Komitetu Wykonawczego ma się odbyć z końcem maja br. w Strassburgu.

W komentarzach powyższego faktu podkreślano, że celem istotnym i konkretnym realizacji planów naszkicowanych w Neuchâtel jest. posunięcie naprzód idei ekumenizmu na płàszczyźnie Liturgii.

„VARIATIONES” w liturgii Wielkiego Tygodnia, opuściły prasę, wysoce starannie wykonane przez Watykańską drukarnię „Poliglotta” jeszcze przed Zwiastowaniem N.M.P. w br.

Variationes" objęły przede wszystkim Wielki Czwartek, który " - po ich myśli - ma być co roku wielkim Swiętem Kapłaństwa. 